\title{
Smart Applications in the Hospitality Business: A Qualitative Study on the City of Eskișehir
}

\section{Banu ZENCİ iD a Oktay EMİ iD b}

a Afyon Kocatepe University, Şuhut Vocational High School, Afyonkarahisar, Turkey. banuzincir26@hotmail.com

b Anadolu University, Open Education Faculty, Eskisehir, Turkey. oktayemir@anadolu.edu.tr

\begin{tabular}{|c|c|}
\hline ARTICLE INFO & ABSTRACT \\
\hline Keywords: & Purpose - The objective of this study is to find out to what extend the hotel establishments in \\
\hline $\begin{array}{l}\text { Tourism } \\
\text { Smart tourism }\end{array}$ & $\begin{array}{l}\text { Eskişehir use smart hotel applications and the opinions and suggestions of hotel managers on the } \\
\text { subject. }\end{array}$ \\
\hline Hotels in Eskişehir & $\begin{array}{l}\text { Design/methodology/approach - The sample of the study consists of hotel establishments in } \\
\text { Eskissehir. The hotel establishments were selected by purposive sampling method and the data } \\
\text { were obtained by structured interview technique. Sound recordings obtained during interviews }\end{array}$ \\
\hline $\begin{array}{l}\text { Received } 10 \text { September } 2019 \\
\text { Revised } 13 \text { November } 2019\end{array}$ & $\begin{array}{l}\text { were transferred to computer and a descriptive analysis was performed considering the notes of } \\
\text { the researcher. }\end{array}$ \\
\hline Accepted 15 November 2019 & $\begin{array}{l}\text { Findings - Hotel managers expressed in general that cost of transition to smart hotel applications } \\
\text { is high, and consequently, hotels in Eskişehir do not use smart hotel applications. }\end{array}$ \\
\hline $\begin{array}{l}\text { Article Classification: } \\
\text { Research Article }\end{array}$ & $\begin{array}{l}\text { Discussion - Although hotel managers are aware of the future advantages of smart hotel } \\
\text { applications, they have argued that cost-benefit analysis should be made carefully. However, } \\
\text { smart hotel applications will provide advantage to hotel establishments in terms of } \\
\text { competitiveness, efficiency and customer satisfaction in addition to cost advantages with the } \\
\text { newly arrived generation } Y \text { and Z. }\end{array}$ \\
\hline
\end{tabular}

\section{Introduction}

Due to the rapid population growth created by urbanization and industrialization, there has been intense migration to cities in many countries of the world today. Many problems such as informality, health, energy and traffic-related problems, waste management, air and water pollution, unplanned urbanization, access to resources and increased crime rates have emerged as a result of this.

While these problems continue to adversely affect the economic and social life in cities, they decrease the quality of life of the residents and weaken the competitiveness of the cities (Harrison et al, 2010:1). In order to solve the problems that arise at this point, the transformation to more livable, quality and functional spaces is accelerated by using information communication technologies (Bilici and Babahanoğlu, 2018:125).

Tourism has smart applications in every step from information production to information communication as in many other sectors. Technological innovations and new approaches involved in tourism industry have formed the basis of different business models. For example, the Computerized Reservation Systems (CRS) created in the 1970s, the Global Distribution Systems (GDS) that emerged in the late 1980s, the introduction of the Internet in the 1990s, and mobile technologies in the 2000s are among the innovations used (Werther et al, 2015). The rapid development of information and communication technologies in recent years has brought about radical changes too. Especially after the Internet of Things (IoT) emerged, travel and tourism are among the most developing sectors (Yalçınkaya et al, 2018:308).

In this study, the use of smart applications in the hospitality sector that is one of the important part of the tourism sector, is discussed and it is aimed to develop recommendations regarding to what extent the hotel establishments in Eskişehir use smart tourism applications by including the opinions and suggestions of the hotel managers about the issue. 


\section{B. Zencir - O. Emir 11/4 (2019) 2601-2611}

\section{Literature (Conceptual / Theoretical Framework)}

Smart tourism has emerged as a result of the use of cloud computing, network communication and other new technologies through the Internet in order to obtain information about tourism resources, tourism economy, tourism activities, etc. Since tourism cannot be considered as only people (tourist) and travel, the joint evaluation of the two together constitutes the infrastructure of "smart tourism" (Li et al, 2017:294).

Information and communication technologies (ICT) and global distribution and central reservation systems in tourism consist of integration of web-based technologies. Smart tourism is also a new generation of communication technology that combines cloud computing, networking and the Internet with personal mobile terminals (3G technology, PDA (personal digital assistant) etc.) and artificial intelligence (Shi, 2013). Gretzel et al (2015:179) defined smart tourism as a term that describes the information and communication technologies that enable the big data of the parties involved in the concept of tourism to convert into value propositions.

Given the information density of tourism and consequently its commitment to information and communication technologies (ICT), computerized communication systems are, of course, the key to the development of smart tourism as well as conceptualization. Smart tourism industry and consumer orientation towards technology has become inevitable through the comprehensive and systematic presentation of information (Gretzel et al, 2015:181).

It has been observed that smart tourism has been created to meet the personal demands of tourists in an ideal way, to increase the satisfaction of tourists and to enable common and extensive share of resources ( $\mathrm{Li}$ et al, 2017:295). Smart tourism, which is dealt with in three ways on the basis of sustainability in international conferences organized by United Nations World Tourism Organization (UNWTO, 2017), is defined as clean, green, ethical and high service quality at every service level. Smart tourism provides a set of solutions that can be implemented by taking into consideration the existing tourism knowledge, infrastructure and management. For this purpose, online tourism services take advantage of digital information and Internet of things to carry out tasks related to tourism such as customer relationship management, operational area management, development of domestic and international tourism markets, collection of tourism information and forecasting of tourism development (Su et al, 2011:1030).

Smart tourism benefits the tourism and travel industry in three ways. First, integration and centralization can be made for the city's tourism information system, making it easier for tourists to access the necessary information and services. Second, cameras can be installed in areas with beautiful views and tourists are provided with real-time viewing. Finally, by analyzing all the data collected at the data center, the needs and demands of tourists can be responded in a minimum time (Zhu et al, 2014:1).

The smart tourism system contains five elements as shown in Figure 1. These elements are the information exchange center, tourists, government, natural areas and establishments respectively. Tourists usually send requests to the Information Exchange Center (IEC) such as ticket search, ticket purchase, booking, social communication etc. Statistics of daily visit data should be reported to IEC for analysis and archiving management. On the other hand, tourism establishments should share statistical data with the government to determine tourism policies (Zhu et al, 2014:1).

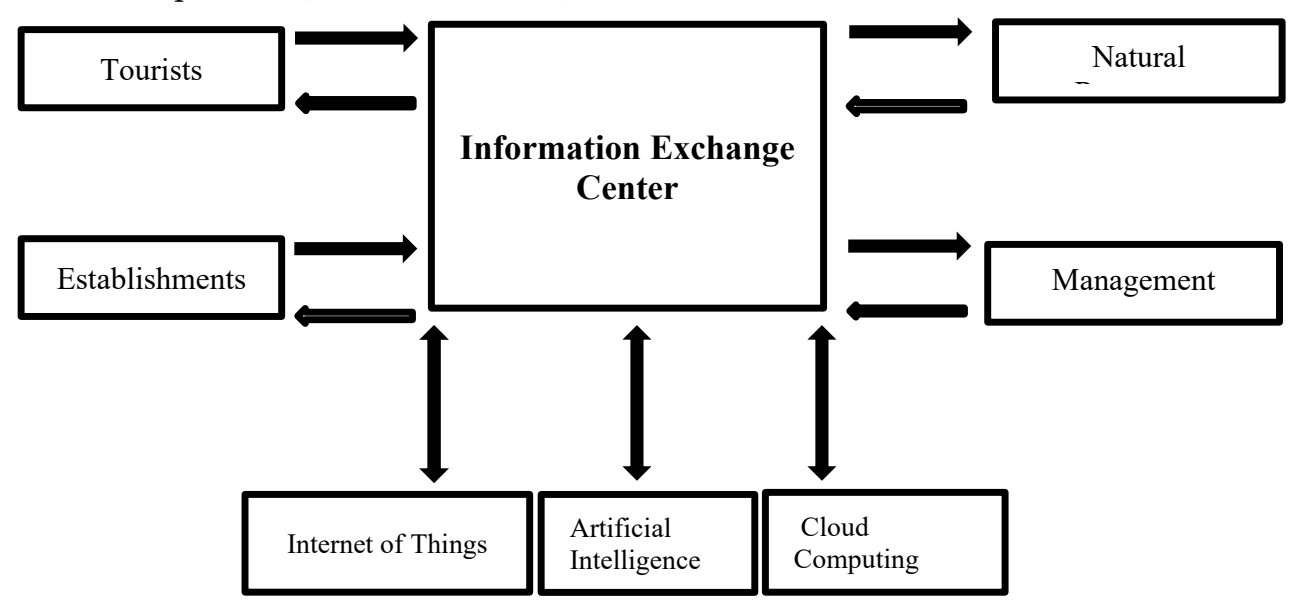

Figure 1. Smart Tourism Structure (Zhu, Zhang and Li, 2014:2). 


\section{B. Zencir - O. Emir 11/4 (2019) 2601-2611}

Smart tourism destinations use information and communication technologies to strengthen sustainable economic development and new collective lifestyles. Information technology (IT), in this context, is considered one of the biggest forces that cause change in the hotel industry. Many hotel establishments consider information technology as a way to cope with globalization, competition, high customer turnover and expectations of increased number of guests (González and Gidumal, 2016:30).

One of the smart applications used in the hospitality industry, radiofrequency wireless controllers provide command-controlled management of air-conditioning, lighting and curtains from any area of the room(s) without the need to point to any receiver. Besides, the room automation systems integrated with the Fidelio reservation system are able to react automatically according to different scenarios, taking into account the booking status of the room. For example, while air conditioning systems are left in economy mode in a vacant room, "set" parameters can automatically change to comfort mode at the time of check-in and operations are reversed in case of check-out (http://bestdergisi.com.tr/arsiv-eski/82-artik-oteller-daha-akilli).

Through mobile room key technology, guests will be able to make digital check-in and use smart technology during room selection. This will ensure that guests who travel frequently and change hotels constantly go directly to their rooms without wasting time at the reception.

Hilton Garden Inn Isparta is the first Hilton branded hotel in Turkey to use Digital Key (https://www.turizmnews.com/akilli-otel-uygulamasi-turkiye-de-ilk-kez Isparta)

In addition, Dedeman Group has announced that they have created a new hotel brand considering the expectations and needs of Generation Y. Smart by Dedeman was created as the third generation hotel brand of the Dedeman Group due to the expectations of young adults known as the generation $Y$ from hotels, price performance, service speed and quality, technological infrastructure, the fact that the hotel is in the city, not paying to hotels for the services not deemed necessary while attaching importance to the originality of the design (http://www.mimarizm.com/haberler).

Henn na Hotel Tokyo Hamamatsucho is the third robotic hotel in Tokyo and the sixth hotel in the country. Providing reception services with a human-looking robot in Tokyo, Henn na Hotel was opened with the concept of "Smart Hotel", which can mostly be controlled from mobile phones. Small robots provide cleaning services at the hotel, where factory-type robotic arms carry your bags to the storage area. In addition to new technologies such as $4 \mathrm{~K}$ TV and VR, the hotel rooms provide services such as steam cleaners for suits of business travelers and there is an additional section called "AI Roboclinic" next to the hotel, which provides robotic technology-supported health services (https://www.webiusdigital.com/)

Besides the activities carried out by the chain hospitality establishments for smart tourism applications, the studies on smart hotel applications conducted in recent years (Tsoutsos et al, 2013) include the project of hotels with nearly zero energy co-financed with the European Commission has been implemented on sixteen pilot hotels operating in the hospitality sector. The project has been implemented in seven European countries (Spain, Greece, Italy, Romania, Switzerland, Croatia and France). The aim of the project is to provide technical support and consultancy by the Commission to the hotel establishments for competitiveness, reduction of energy consumption, adoption of green energy technologies and the sustainability of hotels. The concept of zero-energy hotels has not achieved the desired result in most European countries. The countries and establishments in the European Union were informed that they are required to determine specific policies and take measures to accelerate their energy renewal projects.

In their study, Buhalis and Amarranggana (2014), starting from the development of smart cities, aimed at addressing the resulting opportunities and challenges by investigating the smart applications of smart tourism destinations. Despite some light shed on smart tourism literature, the study has been evaluated within the framework of limitations and it has been found that smart tourism destinations consist of data centers supported by the Internet and cloud computing, focusing on improving the experience of tourists through identification and monitoring of smart things.

In the study of Gua et al (2014), integration of Internet of Things (IoT) technology with smart tourism industry and development of smart tourism cities has been observed. The current situation and development potential of smart tourism in China has been determined and recommendations have been made for applications. Smart tourism is an essential part of building the smart city's implementation system; 


\section{B. Zencir - O. Emir 11/4 (2019) 2601-2611}

it has been stated that it emerged due to the infrastructure of smart city, the use and development of information resources. In addition, it has been observed that tourism IOT including mobile search, mobile positioning, mobile payment, mobile tour guides, virtual offices, social media, interactive communication and other information services, has affected the development. It has been stated that the smart, ecological and technological development of production in China provides the strategic transformation of the tourism industry from online travel to smart travel. In their study, Gökalp and Eren (2016) have developed a smart hotel framework that demonstrates the convenience and innovation of the use of smart technologies in the hospitality industry. In this context, the use of cloud computing within the framework of smart hotel as well as how it will improve the service quality have been discussed by looking at the effect of servqual dimensions such as reliability, responsiveness, empathy, assurance, concrete assets, which have been developed. Smart hotels have been shown to have benefits such as increased revenues, customer satisfaction and employee productivity in addition to reduced staff and inventory costs. Jaremen et al (2016) aimed to define the essence of the smart hotel category and the characteristics of a smart hotel. The subject of management and organization is theoretically based on the literature, and the subject of hotel management and management is expressed using the case study at the PURO hotel in Wrocław. In the study, it was observed that ICT application at Puro Hotel provides measurable advantages for both the establishment and its customers and new technologies have been implemented wherever possible and used in all functional areas. It has been stated that the establishment maximizes its profit with the use of ICT, and besides creating value for the customer, ICT plays an active role in collecting/increasing information and performing its duties. Gonzalez and Gidumal (2016) reviewed in their studies the advantages provided by information technologies to hotel establishments and customers. Qualitative research method based on in-depth interviews was used in the study. Face to face interviews were conducted with the hotel manager, front office manager, housekeeper, food and beverage manager, information technology manager and marketing manager in each of the hotels. A total of 30 interviews were conducted and all were recorded with the permission of the participants.

At the end of the interview, the participants stated the advantages of information technologies including having a green image, a decrease in costs, a decrease in the number of personnel through online check-in transactions, and the realization of customer transactions as soon as possible. It has been found that personalized services are provided, such as reduced customer waiting times and tailoring the atmosphere in the hotel rooms to the customer's wishes. A recent comprehensive model has been presented, showing specific ways in which information communication technologies can follow to improve the organizational performance of the hotel. It has been stated that this model can be taken as a reference frame by academicians and can be used by interested parties to evaluate certain communication and technology options. In a study of Kim et al (2016), they reviewed the green practices of the hotel industry based on the smart tourism system. The effects of smart tourism applications on customer satisfaction were examined in the study considering the evaluation of 217 hotels on TripAdvisor and Expedia sites. 98 of the hotels are chain hotel and 119 are independent. It was observed that, among these, 148 had green sign and 69 had no green sign. $\mathrm{H} 1$ and $\mathrm{H} 2$ hypotheses are green practices are positively related to perceived quality of a hotel and green practices are positively related to customer satisfaction, respectively. The results of the regression showed that hotels pay attention to environmental issues of consumers in the context of accommodation. Molina et al (2011) conducted a survey of 3, 4 and 5-star hotel managers in Spain in order to analyze the use of information and communication technologies by Spanish hotels and evaluate their role as a differentiation tool. The use of information technologies by Spanish hotels has been observed to be high in general. It has been found that the implementation of ICT solutions used by luxury hotels increases the internal efficiency, service quality and thus the image of the hotel for 3 and 4 star hotels. Surprisingly, it is concluded that ICTs are more intensively used in 3-star hotels than in 4-star hotels. The hospitality industry has become very competitive and it has been stated that hotels can improve their efficiency and service quality for their customers by using ICT applications. Uğuz and Ataman (2017) have demonstrated the concept of smart cities and their solutions theoretically based on a literature screening in their study, and it has been aimed to encourage the development of smart tourism projects in Turkey by providing smart destination applications. In addition, in the study many smart solutions have been identified in the fields of health, transportation, security, infrastructure, environment, education and culture. Recommendations have been provided by determining the projects applied to smart cities and smart destinations in the world and Turkey. 


\section{B. Zencir - O. Emir 11/4 (2019) 2601-2611}

Çelik and Topsakal (2017) have evaluated in their study the practices performed in the city of Antalya, an important tourism destination in Turkey, in the context of smart tourism. In the study, the theoretical framework related to the smart tourism destination, which is the subject of the study, has been evaluated and a case study including document analysis and observation methods has been carried out in order to obtain data on smart tourism applications of Antalya. When the works for making Antalya a smart tourism destination are reviewed, it is observed that the processes have been started and Antalya is at the top of the road. Yalçınkaya et al (2018) aimed to contribute to the Turkish literature by evaluating the literature related to the concept of smart tourism and the practices in the tourism sector. The definitions of smart tourism, smart destination and smart hotel in the literature have been found to be more focused on information and communication technologies (ICT). In the academic literature, it was revealed that the environmental dimension of the concept of smart tourism has been ignored. The connection of the concept of smart with technology has been highlighted. On the other hand, the World Tourism Organization emphasized the environmental dimension of the concept when defining the concept of smart tourism, and it was concluded that environmental awareness mentality should be emphasized when defining the concepts of smart tourism, smart destination and smart hotel. Atalay et al, (2018) aimed to evaluate the services provided to tourists during the stay on the basis of smart hotel applications along with technological developments. Qualitative research method was used in the study and internal triangulation method was used to increase the validity and reliability of the study. It has been determined that four 4- and 5-star hotels, which are determined that they use smart hotel applications in Istanbul, can be evaluated within the scope of the study by using their corporate websites and current publications in the media. It was concluded that, in the study, the concept of smart hotel was implemented within the scope of two themes including mobile applications and personalized services. It was determined that 'one touch application ', 'online check-in' and 'online check-out' services were used within the scope of mobile applications while 'user profile note' personalized room service application was used within the scope of personalized services. In addition, it is concluded that the cost of automation infrastructure required for smart hotel applications is high and, as a result of this, a very limited part of the smart hotel criteria could be realized in the hotels covered by the study.

\section{Method}

Case study design was utilized in this study within the scope of qualitative study method. Case study is an approach that aims to reveal the impact or relationship on an individual, participant or society through indepth examination and understanding without interfering with a particular situation (Akar, 2016:117).

The descriptive study model was used in the study. As a result of such an analysis, the data is first described in a systematic and clear manner, the descriptions are explained, interpreted, the cause-effect relationships are reviewed and some conclusions are reached (Yıldırım and Şimşek, 2016:240)

During the survey, the following questions were asked to the managers of the hotel establishments.

1.) Can you tell us about the smart hotel applications used in your hotel?

2.) Do you have social media accounts for your hotel? Are they managed locally by you?

3.) Do you use smart card and kiosk in your hotel? For what are they used?

4.) Can you call your hotel rooms smart rooms?

5.) Do you use personnel performance management and smart hotel resource management applications in your hotel?

6.) Do you have a special tracking system for complaints, evaluations and suggestions arrived via social media or online booking systems about your hotel?

7.) Do you think that smart hotel applications in Eskisehir provide convenience to stakeholders, customers, employees and intermediaries in the areas of competition, effectiveness, efficiency, attractiveness and management?

8.) What are the digital policies you plan to implement in the future in light of the current developments in your hotel? 


\section{B. Zencir - O. Emir 11/4 (2019) 2601-2611}

It was concluded that the most appropriate data collection technique that can be used to find answers to the questionnaire is interview. A comprehensive literature review was conducted in this context in order to form the conceptual framework and to prepare the questionnaire in a qualified manner, and the opinions of experts were asked and the questionnaire was finalized by means of trial interviews.

The main target of the study is hotel establishments in Eskisehir. Participants were selected for purposive sampling. Purposive sampling includes only the selected group in the data collection process by identifying the most appropriate individuals or institutions for the objective of the study (Yıldırım and Şimşek, 2016:240).

The implementability of smart tourism applications was evaluated and 3, 4 and 5-star hotel managers were interviewed. Participants of the study were determined in voluntary basis and 9 hotel managers were interviewed.

Face-to-face interviews were conducted in order to make the data to be collected more reliable. The requests of the participants about not to disclose their names were complied with and code names were assigned to the participating establishments. Interviews were made at the appropriate time and environment by requesting an appointment from the hotel managers. Interviews were conducted with each participant for average 30 minutes during the data collection process. After a total of 270 minutes of interviews were recorded with voice recorder, written transcripts of the interviews were made.

Hotels with different stars were included in the study and multiple realities were achieved in order to diversify (data triangulation) data sources in smart hotel applications. The findings of the study were evaluated by different researchers and their opinions were taken. The results obtained were supported by comparing them with other study results. According to Yıldırım and Şimşek, (2016: 279), the use of diversification strategy in a study is an important method that increases the credibility of the study, but the confirmation of the data obtained by different methods proved that the results obtained increased the validity and reliability of the results.

\section{Findings \& Discussion}

Hotel establishments were coded in the form of A, B, C, D, E, F, G, H, K.

The characteristics of the hotels are given in Table 1.

Table 1. Characteristics of Hotels Participated in the Survey

\begin{tabular}{|c|c|c|c|c|c|c|c|c|}
\hline Hotel & Star & Chain & Hotel & Star & Chain & Hotel & Star & Chain \\
\hline A & 5 & $\sim$ & D & 4 & $\boldsymbol{X}$ & G & 5 & $\times$ \\
\hline B & 5 & $\sim$ & M & 4 & $\checkmark$ & N & 3 & $\checkmark$ \\
\hline G & 4 & $\times$ & F & 5 & $\checkmark$ & F & 3 & $\checkmark$ \\
\hline
\end{tabular}

Can you tell us about the smart hotel applications used in your hotel? The manager of Hotel A stated that the hotels in Eskisehir has no any smartphone application, but the works are going on and the application will be available in their Eskisehir hotel by the end of the year. He/She stated that reservations can be made through the application, services can be used and detailed information about the rooms can be reached. The manager of Hotel B stated that they have a smartphone application that allows making reservations only. $\mathrm{He} / \mathrm{She}$ also stated that information about the hotel can be obtained through the application. The manager of Hotel E stated that they have a smartphone application that allows making booking and check-in He/She also stated that no other service could be reached through the application in their Eskisehir hotel but that the rooms could be checked and the room selection could be made through the application for different hotels. The manager of Hotel F stated that they have no applications for Eskisehir, but they started to work and an application will be released with a special concept hotel in the near future. Manager of Hotel $\mathrm{H}$ stated that they have a general smartphone application under the main brand and that reservations can be made with 


\section{B. Zencir - O. Emir 11/4 (2019) 2601-2611}

the application and information about the hotels under the same brand can be obtained. He/She further stated that they have another smartphone application that can be used by all managers under the hotel brand, providing detailed information about the hotel. He/She also said that check-in process can be made via the current application for the European hotels under the same brand. The manager of Hotel $\mathrm{K}$ stated that they have no any smartphone application, but that some hotels under their brand have developed their own applications, and reservations can be made and information can be obtained on hotels through these applications. Managers of Hotels C, D and G stated that they have no smartphone applications and also no plans to develop smartphone applications in the near future.

Hotel managers generally answered the question "Do you have social media accounts managed by you for your hotel?" that they have social media accounts. Manager of Hotel A stated that they have social media accounts, which were until recently managed by the center to which the hotel is affiliated, but the management was left to them for the first time as a pilot application. The hotel manager stated that they have received services from a professional agency for the management of social media accounts. The managers of hotels C, K, G stated that their social media accounts are managed by themselves. The manager of Hotel D said that their social media accounts were managed by a professional agency. The hotel E manager stated that the social media accounts were managed by the center, but they themselves manage also in accordance with the management's permission. The managers of the hotels $\mathrm{H}, \mathrm{B}, \mathrm{F}$ stated that the social media accounts are managed by the center and local shares are not allowed. As a common opinion, all hotel managers stated that social media accounts have very effective areas of use today but they are not at a level that will make a difference in hotel choice.

Managers of hotels A, B, C, D, E, F, G, H, K replied the question "Do you use smart card and kiosk in your hotel, for what are they used?" as "We do not use smart cards and kiosks". The manager of Hotel A stated that they do not need such a card as their city hotel does not have services that are suitable for smart card use. He/She said that such applications could be used in all-inclusive systems in the Mediterranean Region of Turkey or for services like casino etc. in international hotels. Other hotel managers, as a common opinion, stated that smart card and kiosk applications are not needed in the city hotels as they do not have usage areas.

Although managers of Hotels A, B, C, D, E, F, G, H, K answered the question "Can you call your hotel rooms smart rooms?" as "we cannot call the rooms smart rooms", the manager of Hotel A stated that he/she cannot call the hotel rooms in Eskisehir smart rooms, however, voice assistants have been installed for only the rooms of their hotel in Istanbul and curtain, air conditioner, TV unit, etc. in the rooms will be controlled via voice commands. She/He further stated that, as a result of the experiences to be obtained from this, this system could be installed for the hotel in Eskisehir in the future, if not soon. Manager of Hotel F said that they cannot call the rooms of the hotel in Eskisehir smart rooms, but they will soon open a smart concept hotel under their brands in Istanbul, and the whole hotel will be equipped with smart systems.

The managers of Hotels A, B, D, E, F, G, H, K answered the question "Do you use personnel performance management and smart hotel resource management applications in your hotel?" as they do not use personnel performance management and smart hotel resource management applications. The manager of Hotel $\mathrm{F}$ stated that they receive support from an outside professional company for personnel performance management and that personnel performances are determined by establishing reports issued by the company based on mutual personnel evaluation. The manager of Hotel $\mathrm{C}$ said that, in relation to the personnel, there are finger recognition systems on all doors, that the entrances and exits can be followed in this way and that all personnel are checked in a healthy way since the hotel does not have a large area.

The managers of Hotels $\mathrm{H}$ and $\mathrm{E}$ answered the question "Do you have a special tracking system for complaints, evaluations and suggestions arrived via social media or online booking systems about your hotel?" as they purchase reporting service on this subject from an international company and made the necessary arrangements in accordance with the complaints and suggestions. He/She stated that this service is provided by all hotels in the group and they attach great importance to customer demands. Other hotel managers told that they respond to customers who reach them via online booking systems and social media, through these platforms again and that all complaints, comments and suggestions that will benefit them are taken into consideration. 


\section{B. Zencir - O. Emir 11/4 (2019) 2601-2611}

The manager of Hotel A answered the question "Do you think that smart hotel applications in Eskisehir provide convenience to stakeholders, customers, employees and intermediaries in the areas of competition, effetiveness, efficiency, attractiveness and management?" as services they provided to guests staying under the hotel brand at the hotel when they stay in the city of $x$ are reflected in their profile records, and when they arrive in Eskisehir, they are provided this service without requesting by the guests themselves (for example, a guest who has a pet is recorded in the system of the hotel in the city of $\mathrm{X}$ ) and this will create a competitive advantage. He/She further stated that it is aimed to create a sense of personal satisfaction which is important today by accurate analysis of data through smart systems that are structured correctly between hotels. The manager of Hotel B stated that in this sector, which is mainly based on people, competitive advantage will occur in providing fast solutions to problems through friendly and high quality service, and smart hotel applications in Eskisehir will not provide a great advantage and convenience. The manager of Hotel D provided importance level options from "1 Unimportant to 5 Very important" for the terms in the question including important for "the effect of smart hotel applications on competition, effectiveness, efficiency, attractiveness and management and very important for "the effect on effectiveness and customers" and indecisive for "effect on stakeholders and intermediaries". Manager of Hotel E said that technological change is inevitable, that it will have an impact in terms of competition, healthy use of smart systems and analysis of different data will make it easier for managers. Manager of Hotel F stated that Eskisehir hotels have a more traditional service structure, smart hotel applications will not provide much convenience in city hotels providing this kind of service, transformation will bring a big cost and there is no such requirement at this stage. The managers of Hotels C and G stated that technological transformations should be kept up, that the establishments operating in the service sector cannot remain insensitive to the needs of the era, however, that smart hotel applications in the region where the hotel is located will not provide any convenience depending on different factors.

The manager of Hotel $\mathrm{H}$ stated that everything should be shaped according to need, by developing an application on the basis of city and contribution to the tourism and economic income of the city can be ensured by contributing to this application by the establishments operating in different sectors in Eskisehir. The manager of Hotel $\mathrm{K}$ stated that the competitive advantage in particular in Eskisehir can be achieved by price and quality balance in the near future, not by smart applications. He/She further said that smart applications can be implemented as a concept especially for new hotels, however, it is not necessary in Eskisehir for now.

The manager of Hotel A answered the question "What are the digital policies you plan to implement in the future in light of the current developments in your hotel?" as the development of a smartphone application will be completed and put into service as soon as possible, and the maximum data exchange between the hotels is made to create a sense of belonging in order to make the customer feel special. The manager of Hotel B stated that by further improving the existing smartphone application, they are considering providing many services such as ordering for the room through the application and seeing the restaurant menu in the hotel through the application. He/She additionally stated that all hotels under the brand have a system that is accessible to them, that the situations such as malfunctions, customer dissatisfaction etc. are recorded in the system and different solutions are produced through continuous connection through the system. The manager of Hotel D stated that they would like to facilitate access to people, for example, by sending information messages about their hotel to people passing by or arriving in the city. Managers of hotels $\mathrm{C}, \mathrm{E}$ and $\mathrm{K}$ stated that they do not have a digital policy in the near future, however, they are open to all kinds of developments that will facilitate digital transactions. The manager of Hotel F stated that their hotel brand have developed a separate hotel concept as a digital policy, for especially Eskisehir, they do not have any digital policies in the near future. The manager of Hotel G stated that they have digital policies that they plan to implement in the coming years in terms of customer satisfaction, that these can evolve in the process and that easy implementability is aimed. The manager of Hotel $\mathrm{H}$ stated that their most important digital policy is to create the most accurate profiles of customers by making each customer a digital card holder. He/She further stated that, in the light of the information collected through a membership system, they will have the opportunity to respond to customers' requests and needs in the most accurate way, collected points in the card as a result of accommodations can be used as accommodation in their own hotels or in different hotels under the brand name or can be used for different service purchases in other contracted establishments. 


\section{B. Zencir - O. Emir 11/4 (2019) 2601-2611}

\section{Conclusion}

It is seen that the profitability of digitized companies is $25 \%$ above the sector average and has a positive impact on economic development (https://www.tursab.org.tr). In this context, digitalization that affects all sectors, deeply affects the tourism sector and creates new trends. Customer expectations are inevitably changed according to digital trends. Following this change, Internet of things, cloud system, robotization, NFC, GPS and smart applications started to be used in tourism sector. In the nine hotels included in the study, it was found that many of the services provided by the smart hotel concept (Internet of thing, cloud system, robotization, NFC) developed by Gökalp and Eren (2016) were unavailable. Hotel managers stated that the following up smart technologies and smart applications is of great importance for the sustainability of the establishment, however, that smart applications will bring additional financial burden to the establishment.

They clearly stated that, even if these costs are incurred especially in Eskişehir, the applications will not have positive effects in terms of demand and customer satisfaction, and that cost benefit analyzes should be performed very well and that all investments should be decided accordingly.

Although $87 \%$ of hotel establishments in Turkey stated that the contribution of smart hotel applications to tourism would be high, (https://www.tursab.org.tr), it is stated that smart applications are not used enough by hotels when the studies on smart hotel applications are reviewed (Çelik and Topsakal, 2017; Atalay et al, 2018). According to the studies, smart applications should be used for new investments rather than adapting them to existing hotels.

Hotel managers interviewed in Eskişehir stated that although smart hotel applications do not have an implementation area in their own hotels, personnel and inventory costs can be reduced, revenue increase can be achieved and customer and employee satisfaction can be increased in this way. However, they pointed out that talent losses may be experienced in terms of human resources, that job sites will be narrowed and that these will have negative effects on personnel standards.

Topsakal and Bahar (2018: 255) stated that the introduction of smart hotel applications in hotels will create a need for new personnel who can use these technologies, which means that those among the old personnel, who cannot adapt may lose their jobs or that there may be a loss of talent in terms of human resources.

Previous studies on smart hotel applications (Tsoutsos, 2013; Gökalp and Eren, 2016; Atalay et al, 2018, Gonzalez and Gidual, 2016; Molina, 2011; Topsakal et al, 2018) have shown similar results to other studies. It is known that hotel managers consider that ICT applications provide convenience to stakeholders, customers, employees and intermediaries in the areas of competition, effectiveness, efficiency, attractiveness and management, however, Jaremen et al (2016) stated that ICT applications do not provide measurable advantages for establishments and customers.

It should be noted that in these days the $\mathrm{X}, \mathrm{Y}$ and $\mathrm{Z}$ generations live together, the different communication styles and lifestyles of the three generations are unique. In this context, shaping of the needs of the society according to generation $\mathrm{Y}$ and $\mathrm{Z}$ by decreasing of the effectiveness of generation $\mathrm{X}$ in the society will shape all service establishments according to the desires of these generations and force them to transform. For this reason, even though hotel establishments think that they have made the right decision in the short term by evaluating the transformation to smart applications especially in terms of costs, their failure to keep up with the rapid transformation will result in loss of too many customers and satisfaction. Enterprises are established for an infinite period of time and they need to keep up with the changing and developing era with all their dynamics in order to maintain their lives in a healthy way. According to the studies, it is very important for all hotel establishments in tourism sector and especially in Eskişehir to develop strategies by including innovations in digital channels in their planning and promotion, and to select managers especially from generation $\mathrm{Y}$ and $\mathrm{Z}$, regarding development and change of tourism establishments.

Discussing smart hotel applications in different ways in future studies will be useful for understanding and developing the subject. The lack of smart hotel practice in Turkey, investigation of smart applications started to be used in hotels for awareness of visitors and staff, comparison of establishments use or using of not using this technology, will be a guide for future digital strategies. 


\section{B. Zencir - O. Emir 11/4 (2019) 2601-2611}

\section{References}

Akar, H. (2016). Durum Çalışması, Şaban, A. ve Ersoy, A. (Ed.), Eğitimde Nitel Araştırma Desenleri, Anı Yayınevi, Ankara, 113-149

Akbiyık, C. ve AY, G. K. (2014). Okul öncesi yönetici ve öğretmenlerin düşünme becerilerinin öğretimine yönelik algıları: bir durum çalışması. Hacettepe Üniversitesi Eğitim Fakültesi Dergisi, 29(1), 01-18

Atalay, L. ve Yalçınkaya, P. ve Bahar, F. (2018). İstanbul'daki akıllı otel uygulamalarının değerlendirilmesi. Manas Sosyal Araştırmalar Dergisi, 8(1), 667-678.

Buhalis, D., \& Amaranggana, A. (2014). Smart Tourism Destinations, Dublin, IFITT

Bilici, Z ve Babahanoğlu, V. (2018). Akıllı kent uygulamaları ve Konya örneği. Akademik Yaklaşımlar Dergisi 9 (2), 124-139.

Çelik, P. ve Topsakal, Y. (2017). Akıllı turizm destinasyonları: Antalya destinasyonunun akıllı turizm uygulamalarının incelenmesi. Seyahat ve Otel İşletmeciliği Dergisi 14 (3), 149-166.

Gonzalez, S. M. and Gidumal, J. B. (2016). A model that connects information technology and hotel performance. Tourism Management 53, 30-37

Gökalp, E. ve Eren, E. (2016). Akıllı Teknolojilerin Turizm ve Otelcilik Sektöründe Uygulanması. Tecim, V., Tarhan, Ç. ve Aydın, C. (Ed). Akıllı Teknoloji \& Akıllı Yönetim, Gülermat Matbaacılık, İzmir, 278-287.

Gretzel, U., Sigala, M., Xiang, Z. \& Koo, C. (2015). Smart tourism: foundations and developments. Electron Markets 25, 179-188.

Guo, Y., Liu, H., \& Chai, Y. (2014). The embedding convergence of smart cities and tourism Internet of Things in China: An advance perspective. Advances in Hospitality and Tourism Research (AHTR), 2(1), 54-69.

Harrison, C., Eckman, B., Hamilton, R., Hartswick, P., Kalagnanam, J., Paraszczak, J. ve Williams, P. (2010). Foundations for smarter cities, IBM Journal of Research and Development, 54 (4), 1-16.

http://bestdergisi.com.tr/arsiv-eski/82-artik-oteller-daha-akilli/ (E.T: 22.07.2019).

http://www.mimarizm.com/haberler/gundem/y-kusagina-ozel-otelkonsepti-smart-by-dedeman_128030) (E.T: 22.07.2019).

https:/www.turizmnews.com/akilli-otel-uygulamasi-turkiye-de-ilk-kez isparta-da/12773/)/ (E.T: 22.07.2019).

https://www.webiusdigital.com/otelcilik-sektorunde-yapay-zeka uygulamalari/ (E.T:22.07.2019).

https://www.tursab.org.tr/apps//Files/Content/ad5f3ddb-5a11-410f-9e3c-fe8b2dc4df8b.pdf (E.T:22.07.2019).

UNWTO. (2017). Innovation, technology and sustainability - pillars of Smart Destinations. https://media.unwto.org/press-release/2017-02-21 (E.T: 22.07.2019).

Jaremen, D. E., Jędrasiak, M. \& Rapacz, A. (2016). The concept of smart hotels as an innovation on the hospitality industry market - case study of Puro Hotel in Wrocław. Economic Problems of Tourism, 36 (4), 65-75.

Kim, J.Y., Hlee, S. \& Joun, Y. (2016). Green practices of the hotel industry: analysis through the windows of smart tourism system. International Journal of Information Management, 36(6), 1340-1349.

Li, Y., Hu, C., Huang, C., \& Duan, L. (2017). The concept of smart tourism in the context of tourism information services. Tourism Management, 58, 293-300

Molina, M. E. R., Saura, I. G. \& Velázquez, B. M. (2011). Does technology make a difference? Evidence from Spanish hotels https://link.springer.com/content/pdf/10.1007\%2Fs11628-010-0098-y.pd (E.T: 15.07.2019).

Shi, Y. (2013). The next generation of communications technology in the era of economic experience: Smart tourism application. Technological Horizon, 9, 180-193 


\section{B. Zencir - O. Emir 11/4 (2019) 2601-2611}

$\mathrm{Su}, \mathrm{K} ., \mathrm{Li} \mathrm{J} . \& \mathrm{Fu}, \mathrm{H}$. (2011). Smart city and the applications in electronics, communications and control (ICECC). International Conference on IEEE, 1028-1031.

Tsoutsosa, T., Tournakia, S., Santosb, C. A. \& Vercellottic, R. (2013). Nearly zero energy buildings application in mediterranean hotels. Energy Procedia 42, 230-238.

Uğuz, S. Ç. ve Ataman, H. (2017). Akıllı şehir uygulamaları ve turizm: Türkiye örneği. Uluslararası Sosyal Araştırmalar Kongresi (Uşak'17). 20-22 Nisan 2017 / İstanbul

Werther, H., Koo, C., Gretzel, U. \& Lamsfus, C. (2015). Special issue on smart tourism systems: convergence of information technologies, business models, and experiences. Computers in Human Behavior, 50, 556557.

Yalçınkaya, P., Atay, L. ve Korkmaz, H. (2018). An evaluation on smart tourism. Journal of Gastronomy and Travel Research 2,(2), 34-52,

Yıldırım, A. ve Şimşek, H. (2016). Sosyal Bilimlerde Nitel Araştırma Yöntemleri, Ankara, Seçkin Yayınevi

Zhu, W., Zhang, L.,\& Li, N. (2014). Challenges, function changing of government and enterprises in Chinese smart tourism, In Z. Xiang \& L. Tussyadiah (Ed.), Information and Communication Technologies in Tourism 2014. Springer, Dublin

Topsakal, Y., Yüzbaşıŏ̆lu, N. ve Bahar, M. (2018). Endüstri 4.0 çağında 'akıllı' olma yolunda oteller için öneriler. The Second International Congress on Future of Tourism: Innovation, Entrepreneurship and Sustainability. September 27-29, Mersin/ Turkey. 